\title{
REAL-TIME SURFACE-WATER MONITORING IN NEW JERSEY, 2003
}

A network of 93 gaging stations that provide surface-water stage, flow (discharge), and tide-level data on a "realtime" basis through satellite, radio, and telephone telemetry is operating (May 2003) in New Jersey through a cooperative effort of the U.S. Geological Survey (USGS) and other agencies. The stream data from these stations are transmitted every 1 to 4 hours and then are immediately posted for viewing on the Internet. This fact sheet describes the "real-time" monitoring network, and the equipment used to measure stage and flow and to transmit the data for viewing on the Internet. Instructions for viewing the data are included. The agencies cooperating in the operation and maintenance of the "realtime" surface-water data network are

$\begin{array}{lll}\text { U.S. Army Corps of Engineers } & \text { Hunterdon County, N.J. } & \text { Perth Amboy Water Department } \\ \text { U.S. Department of Defense } & \text { Somerset County, N.J. } & \text { Princeton Sewer Operating Committee } \\ \text { N.J. Dept. of Environmental Protection } & \text { Union County, N.J. } & \text { Westwood Borough, N.J. } \\ \begin{array}{l}\text { N.J. Dept. of Transportation } \\ \text { Essex County, N.J. }\end{array} & \text { Brick Township Municipal Utilities } & \text { Lake Hopatcong Commission } \\ & \text { Authority } & \text { N.J. Water Supply Authority. }\end{array}$

\section{Background}

This statewide network consists of several sub-networks that were created to provide time-critical surfacewater data as well as information on long-term hydrologic conditions and trends in stream stage, flow (discharge), and tide levels within the State of New Jersey and to make the data available quickly. The gaging stations in these "real-time" networks, located throughout New Jersey (fig. 1), provide time-critical information for the monitoring of floods, droughts, and daily streamflow conditions needed for public safety; water-supply management; and the daily operations of water supply and receiving-water discharges. This combined statewide network, for example, provides data that allow for timely flood warnings to the public and evacuations in flood-prone areas. The system provides upto-date observations of drought conditions for the optimum management of water supplies and up-to-date information on streamflow conditions for fishermen, canoeists, kayakers, boaters, and other recreational users. In addition, the data from this network can be used to estimate the most recent stream and tide conditions at nearby stations that do not have satellite telemetry.

Surface-water stage and streamflow information typically is used by engineers, planners, water-supply managers, emergency-management personnel, and the general public for a variety of purposes. Some of the uses for this streamflow information include incorporation into the design of bridges, dams, flood detention and control struc-

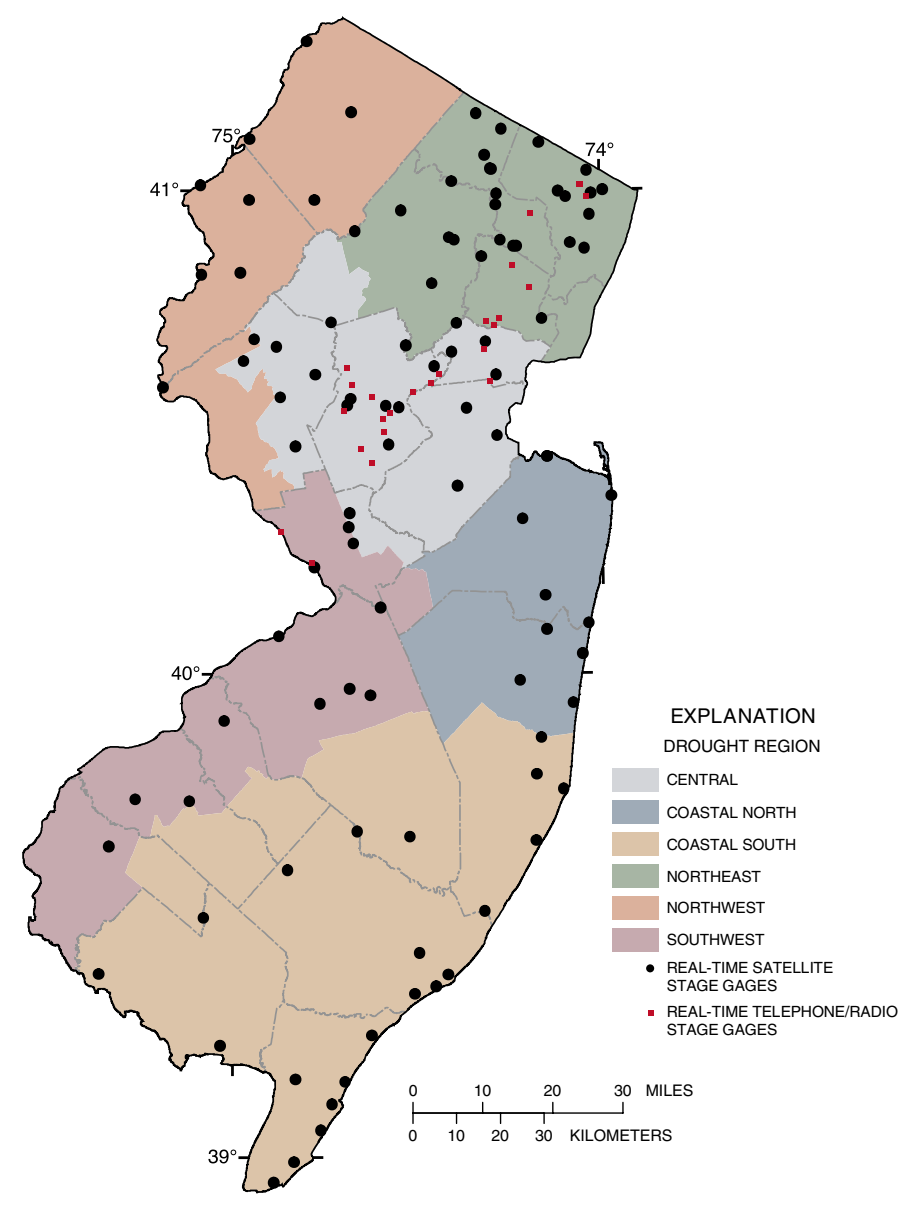

Figure 1. Location of current and planned gages that transmit "real-time" stage data. 
tures, and waterways, and consideration of up-to-date information on river water levels and streamflows for water-supply management, wastewater-treatment plant design and permitting, flood and drought warning and management, and long-term trend analysis. In addition, the general public often finds this information valuable for planning and decision making for outdoor recreational activities involving the State's waterways. The most critical use of "real-time" data are for flood monitoring and the timely evacuation of residents and the general public from flood-prone areas. In addition, during droughts the "real-time" data are used to keep water-supply managers and the general public accurately informed so that sound and timely water-supply management decisions can be made.

\section{Description of the Network}

Most continuous recording gaging stations are located on large streams with drainage areas of 10 square miles or more. The "real-time" statewide networks of gaging stations are part of several existing networks established for stream flood warning, coastal tide and storm-surge flood monitoring, and drought warning. Specifically these networks include the Passaic Flood Warning System, Somerset County Flood Information System, Rahway River and Pascack Brook Flood Warning Systems, New Jersey Tide Telemetry System, and New Jersey Drought Monitoring System. Fact sheets that describe the Somerset County Flood Information System (Summer, 1998a), Passaic Flood Warning System (Summer, 1998c), and Tide Telemetry System (Summer, 1998b) can be found at the http: //nj.usgs.gov/ web site.

Most "real-time" gaging stations report both current stage and streamflow conditions. Gaging stations located in coastal back-bay areas generally report only tide-stage information. Some "real-time" stations provide information

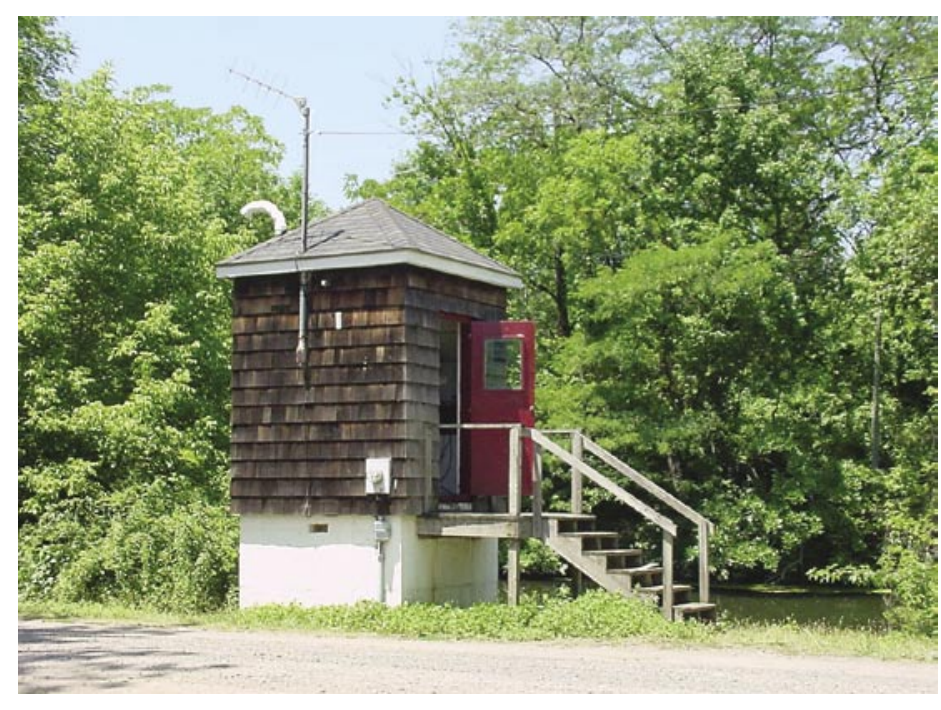

Figure 2. Typical "real-time" surface-water gaging station equipped with a data-collection platform and satellite antenna. on local weather and water quality. Other characteristics recorded and transmitted at these sites include, but are not limited to, water and air temperatures, wind direction and speed, rainfall, barometric pressure, dissolved oxygen, $\mathrm{pH}$, specific conductance, and turbidity.

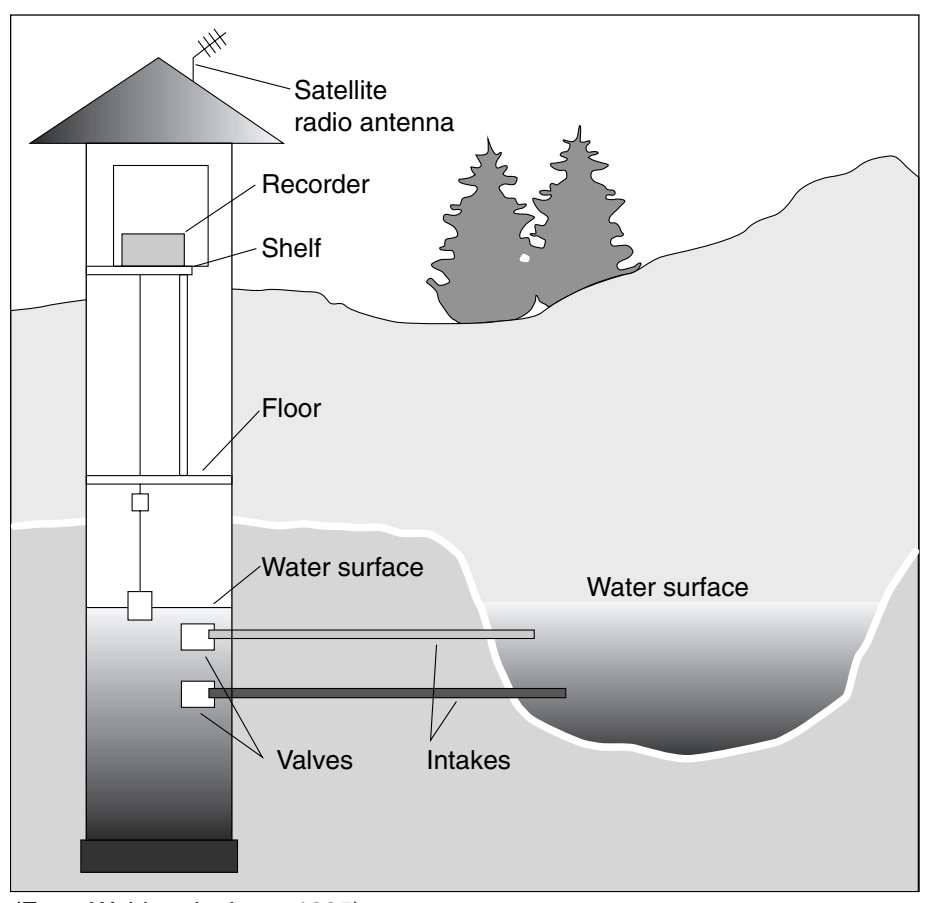

(From Wahl and others, 1995)

Figure 3. Schematic drawing of a stilling well and shelter at a streamgaging station.

\section{Description of Data Collection and Reporting System}

The stream stage (the level of the stream typically measured in feet above a datum point) or tide level at each station in the network is automatically measured at 6- or 15-minute intervals, and the value is stored by a data-collection platform (DCP) located on site (fig. 2, fig. 3, and fig. 4).

Every 1 to 4 hours, a burst of data is broadcast from the site to the National Oceanic and Atmospheric Administration's GOES (Geostationary Operational Environmental Satellite) satellite and relayed to a ground station. The data then are retransmitted by the DOMSAT (commercial) satellite to a USGS ground station, decoded, and automatically posted to the USGS, New Jersey District, Internet web page for viewing (fig. 5). Radio and telephone telemetry at some of the surface-water stations provides either an alternate pathway or, for some critical surface-water stations, a more direct pathway for the transmission of "real-time" information. The stage data for most of the stream-gaging stations are used to compute the stream discharge (the flow of the stream, typically measured in cubic feet per second) using an established relation between stage and flow, referred to as a rating curve. 


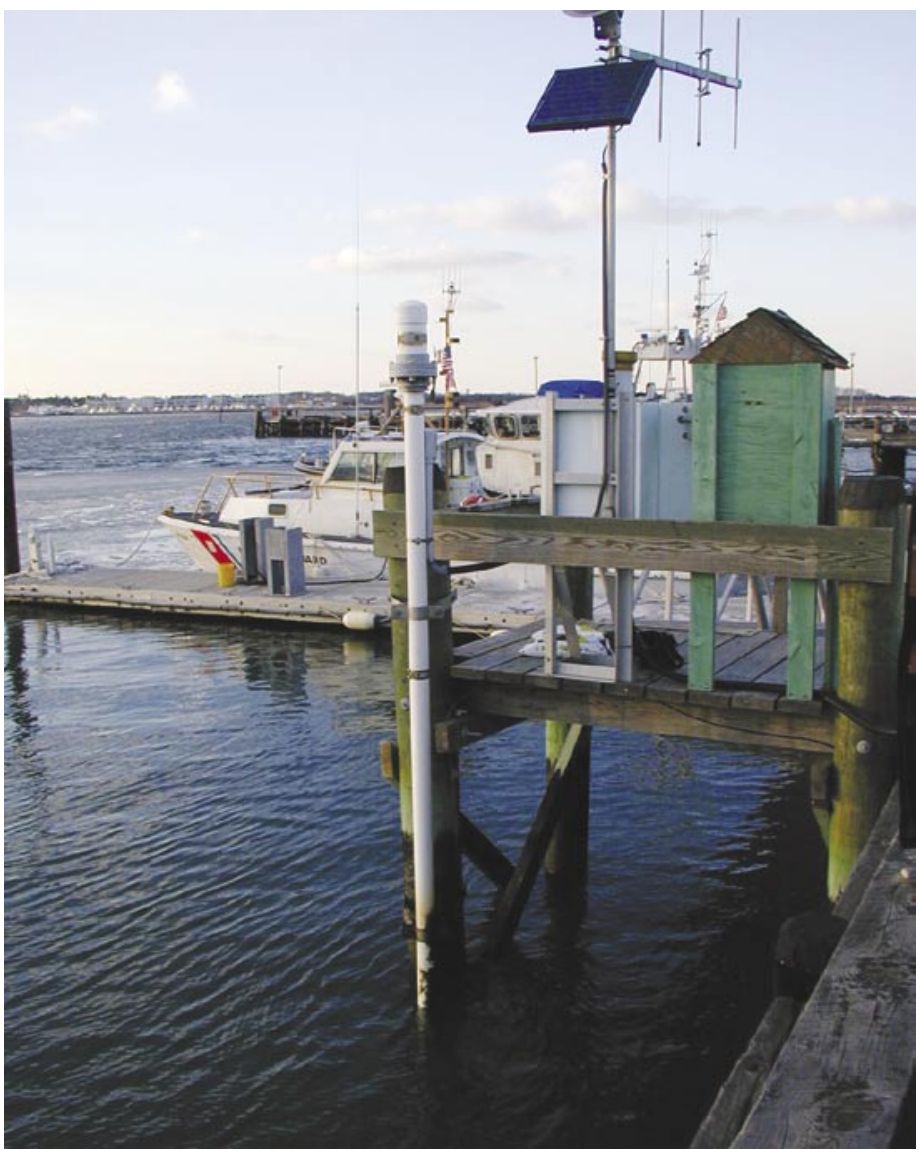

Figure 4. U.S. Geological Survey tide gage at Cape May Harbor in Cape May, N.J., which transmits tide elevation and meteorologic data via satellite and VHF radio for emergency management and other purposes. (Photograph by Peter B. Reilly, U.S. Geological Survey)

To ensure the accuracy of the data, each station is visited every 6 to 8 weeks by a USGS hydrographer who makes field measurements of stage and discharge, checks the automated systems, and performs maintenance on the equipment. The field measurements of stage and discharge then are used to verify the relation of stage to discharge.

\section{Where to View Data}

The surface-water data from this network can be viewed by following these instructions:

\section{Attach to the Internet web page, http://} waterdata.usgs.gov/nj/nwis/current/?type=flow/ . This page lists each gaging station in the network and indicates the latest reported data.

2. Choose a gaging station by clicking on its Station Number. This leads to a page that contains a hydrograph of the stage and discharge data for the last 7 days (fig. 6) and a summary of the daily mean flow statistics. The hydrograph will have indicators for daily median flow and flood-stage levels, as appropriate.

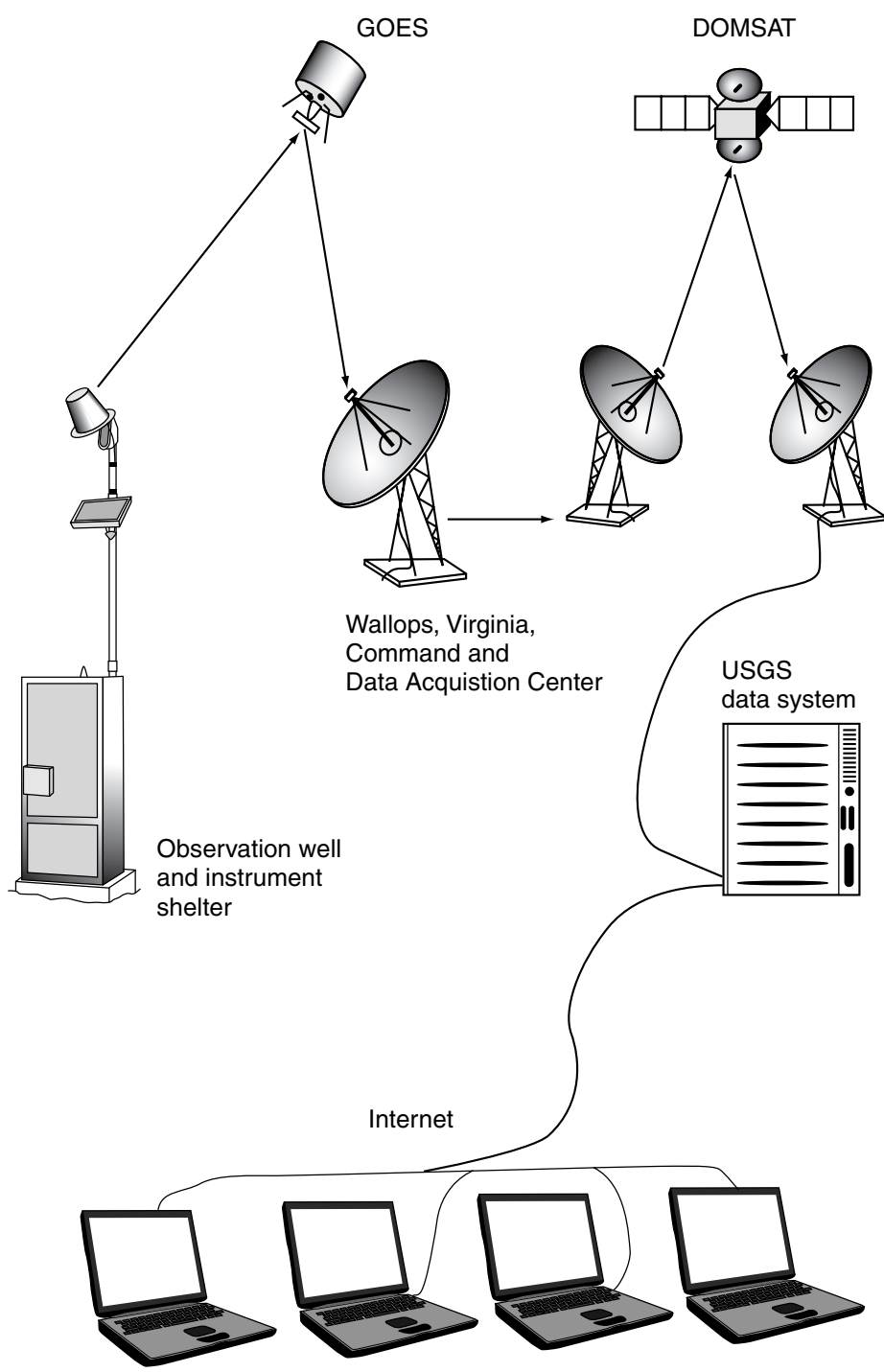

Figure 5. Schematic drawing showing data transmission from a gaging station through satellite telemetry to users on the World Wide Web.

3. The timeframe for a hydrograph can be modified from the past 7 days up to the past 31 days by changing the value for "Days" in the box located above the hydrograph and then clicking on the "get data" button. A new hydrograph will then be drawn. Note that clicking on the indicated text will draw a presentation-quality hydrograph that can be downloaded easily and printed by the viewer.

The daily mean flow statistics are provided on the web page to put the stage and discharge data in a historical context. The maximum, mean, and minimum flows (discharge) for the period of record for the gaging station are indicated. The 80, 50, and 20 percent exceedence values that are indicated are the flows that were surpassed by 80,50 , and 20 percent, respectively, of all daily mean flows. The latest flow value (obtained from the table or from the hydrograph) can be compared to these statistics.

Because the stage and flow data are shown automatically, the message "Provisional data subject to revision" is 


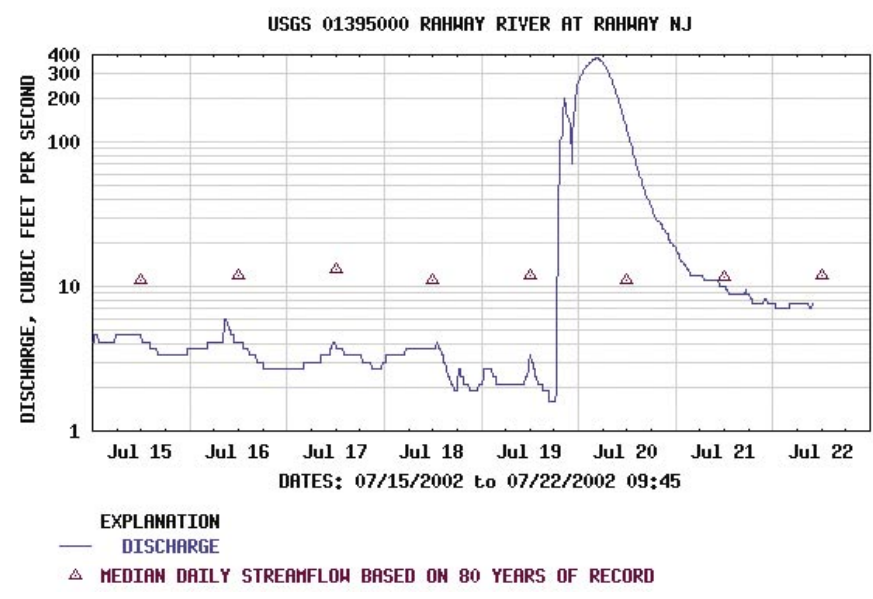

Figure 6. Example of an actual streamflow hydrograph that can be viewed and printed from the "real-time" network web page.

included on the web pages. If problems with the measurement, communication, or storage systems are found, revisions will be made to the USGS database at a later time to provide the corrected values.

The surface-water stations with radio telemetry that are a part of the Passaic Flood-Warning System transmit on an event reporting basis and update as frequently as every 5 minutes. This more frequent "real-time" data can be viewed at http://www.afws.net/ .

USGS, in cooperation with New Jersey Department of Environmental Protection and other agencies, regularly measures stage and flow at 27 other gaging stations in New Jersey. The data from these stations, although not posted on a "real-time" basis, are available on the web site http://waterdata.usgs.gov/nj/nwis/sw/ . Surface-water data for all stations routinely monitored by USGS, including those of the "real-time" network, are summarized in an annually published report (for example, Reed and others, 2002).

The ultimate goal of the USGS and other cooperating agencies is to have all surface-water gaging stations in New Jersey equipped with "real-time" telemetry equipment. Navoy

\section{References Cited}

Reed, T.J., White, B.T., Centinaro, G.L., Dudek, J.F., Spehar, A.B., Protz, A.R., Shvanda, J.C., Watson, A.F., and Holzer, G.K., 2003, Water Resources Data, New Jersey, Water Year 2002, Volume 1. Surface-Water Data: U.S. Geological Survey Water-Data Report NJ-02-1, 364 p.

Summer, W.M., 1998a, Somerset County Flood Information System: U.S. Geological Survey Fact Sheet FS-090-98.

Summer, W.M., 1998b, New Jersey Tide Telemetry System: U.S. Geological Survey Fact Sheet FS-091-98.

Summer, W.M., 1998c, Passaic Flood Warning System: U.S. Geological Survey Fact Sheet FS-092-98.

Wahl, K.L., Thomas W.O., Jr., and Hirsch, R.M., 1995, The stream-gaging program of the U.S. Geological Survey: U.S. Geological Survey Circular 1123, 22p.

\section{Related Internet Links}

- The home page for the NJDEP is http://www.state.nj.us/dep/ .

- The home page for the NJDEP Water Supply Administration, which has information related to drought policy and declaration, is http://www.state.nj.us/dep/watersupply/ .

- The home page for USGS water-resources information for New Jersey is http://nj.usgs.gov/ .

For additional information contact:

District Chief

U.S. Geological Survey

810 Bear Tavern Road, Suite 206

West Trenton, New Jersey 08628

Telephone number: 609-771-3901

Email: dc_nj@usgs.gov 